\title{
Effect of endophytic fungi on plant growth and blast disease incidence of two traditional rice varieties
}

\author{
D.M. Atugala and N. Deshappriya* \\ Department of Botany, Faculty of Science, University of Kelaniya, Kelaniya.
}

\begin{abstract}
Traditional rice varieties, although low producers of yield, are more amenable to organic farming practices that cause less damage to the environment and human health. Improved growth and reduced disease incidence would produce higher yields, and endophytic fungi have proven to be effective in achieving these ends in wheat. With this in view, endophytic fungal assemblages of two traditional rice varieties of Sri Lanka i.e. Suwandel and Kaluheenati were evaluated for their effect on the growth and disease incidence of rice plants, because the endophytic mycoflora of these two traditional rice varieties and their effects have not been studied before. The most common and the highest occurring endophytes of both rice varieties i.e. Absidia and Cylindrocladium were tested to determine their effect on rice plant growth and the results showed that the plants inoculated with both fungal isolates showed significant increases $(\mathrm{p} \leq 0.05)$ in plant height, fresh weight and dry weight. Twenty two endophytic fungal isolates common to both rice varieties were screened using dual culture assay for their ability to control the mycelial growth of Magnaporthe grisea, the causative agent of rice blast disease. All tested endophytes controlled pathogen growth by coiling the hyphae around the pathogen and forming clamps and loops. However, Absidia and Acremonium showed the highest growth inhibition of the pathogen $(100 \%)$ and showed an abundance of the above inhibitory structures. The effect of crude culture filtrates of thirteen endophytic fungi tested using the diffusion plate method indicated antagonistic activity against the rice pathogen. In planta tests were carried out to assess the effect of three endophytic fungi i.e. Acremonium, Absidia and Penicillium on infection by $M$. grisea. Disease symptoms were observed only on the leaves of the rice plants grown from Penicillium inoculated seedlings and on plants used as controls sprayed with a $1 \times 10^{7}$ spores $/ \mathrm{mL}$ suspension of the pathogen. Pre-inoculation with Acremonium and Absidia were effective in preventing infection by the blast fungus. No disease symptoms were observed in plants pre-inoculated with endophytes and in plants used as controls sprayed with a $1 \times 10^{5}$ spores $/ \mathrm{mL}$ suspension of the pathogen. Twenty one endophytic fungi common to both rice varieties were assessed by the culture plate method in this study.
\end{abstract}

Keywords: Disease incidence, endophytic fungi, Kaluheenati, Magnaporthe grisea, Suwandel, traditional rice cultivation.

\section{INTRODUCTION}

Traditional rice varieties are amenable to organic farming practices. Therefore, they can be grown using organic cultivation systems, which cause minimal damage to the environment and consumers. In addition to general organic soil management (i.e. incorporating organic residue to soil, improving soil structure with compost etc.), organic rice farming requires specific fertilization and nutrient management (Naturland, 2002). This is achieved by adding organic nutrient sources to the soil and allowing the soil to feed the rice crop. Green manure is preferable to other organic fertilizers because it is easier to handle, comparatively free of harmful microorganisms and more effective in supplying nutrients. Compost of rice straw and animal manure, e.g. poultry manure and cow dung, can also be added if necessary (Naturland, 2002). However, traditional rice cultivation using such practices produces a low yield, which is insufficient to fulfill the current consumer demand. Therefore, it is important to increase the total production and minimize the loss due to diseases.

Plant-associated microorganisms play essential roles in agriculture and food safety, and contribute to maintain environmental equilibrium. Such beneficial microbes can increase the root growth and nutrient uptake of plants, fix nitrogen, decrease plant stress and disease incidence and thus will have a strong influence on the plant growth, development and yield. Some of them can also be useful for developing management strategies for protection against numerous pathogens (Montesinos, 2003). 
Endophytic microorganisms are an example of a group of microorganisms reported to possess such beneficial effects. Due to their capability of colonizing internal tissues of plants and their ability to promote plant growth and to control plant diseases, endophytic microorganisms can be used in agriculture as a tool to improve crop performance (Yuan et al., 2009). In the past two decades, a great deal of information on the diversity and the role of endophytes have been collected (Yuan et al., 2009).

It has been reported that grass species host endophytic fungi that promote plant growth (Baynes, 2011). The grasses Lolium perenne (perennial rye grass) and Festuca arundinacea (tall fescue) are often infected by the imperfect fungi Acremonium loliae and A. coenophialum, respectively. The effect of the fungi on the improved survival, growth and reproduction (i.e., fitness) of their host plants compared to uninfected plants has been reported (Morgan-Jones \& Gains 1982; Latch et al., 1984).

Endophytic fungi have also been reported to protect the host from plant pathogenic fungi and abiotic stresses. Endophytic fungi isolated from the roots of wheat are reported to control the fungus responsible for 'take-all' disease (Coombs, 2002). Rice blast disease caused by Magnaporthe grisea is one of the diseases that cause maximum damage to rice production. Generally, rice blast control is achieved with the use of specific fungicides.

Mechanisms of inhibition of pathogen infection and proliferation within a host can be direct (via antibiosis, competition for substrate and mycoparasitism), or indirect via inducing resistance responses intrinsic to the host (Mejia et al., 2008) and as some endophytic organisms seem to be able to control pathogens with such mechanisms, they could be used in bio control of plant diseases.

The proteins secreted by endophytic fungal spp., are likely to be important components of the mutualistic interaction because they are located at the interface of the two species. Some of these proteins function in the extraction of nutrients from the plant apoplast and therefore important for fungal growth. These proteins are also reported to suppress plant pathogen activities directly by acting as pathogenicity related (PR) proteins. One function attributed to this is degradation of cell walls of the pathogenic fungi (Li et al., 2004).

In the present study, the effect of some of the frequently isolated fungal endophytes on the growth of two traditional rice varieties was evaluated. Endophytes may be transmitted either vertically or horizontally. Vertically transmitted fungal endophytes are asexual and transmit via fungal hyphae penetrating the host's seeds, i.e. Neotyphodium is passed to the next generation of turf grass plants through the seeds (Sawka, 2004). Therefore, two types of seeds i.e. long storage seeds and recently harvested seeds from both varieties were used to inoculate the tested fungi. According to Li et al. (2004), seeds that have lost the viable endophyte as a result of long-term storage, and resultant plants from long term storage germinated seeds are endophyte-free. Long storage seeds (LSSs) from both varieties, which have been stored at $1^{\circ} \mathrm{C}$ for 20 years were selected as endophyte free controls for this study.

Endophytic fungi isolated from various plant parts of the two rice varieties used in the present study were evaluated for their effect on the rice blast pathogen, with the view of using them as an alternative method of controlling the disease. Some of the endophytes isolated in the present study were evaluated for their capacity for enzyme production, which would be useful in understanding their mechanism of action in reducing disease incidence.

In addition, some of the fungal endophytes isolated from both Suwandel and Kaluheenati were evaluated for their effect on the growth of plants of the respective variety that they were isolated from, inhibition of the pathogen growth as well as the mechanisms involved with the antagonistic activity towards the rice blast pathogen. This was aimed at developing an inoculum, which can be used to improve the performance of traditional rice varieties, especially when using organic farming practices.

\section{METHODS AND MATERIALS}

\section{Isolation and identification of endophytic fungi from different plant parts and seeds of the varieties Kaluheenati and Suwandel}

Eight-week old, healthy and intact rice plants of the varieties Kaluheenati and Suwandel (10 plants of each variety) with an average height of $72.6 \mathrm{~cm}$ and $74.3 \mathrm{~cm}$, respectively without blemishes on the leaf blades and sheaths and without signs of root diseases were collected randomly with bulk soil from the fields at Naranwita, Sri Lanka. Leaf pieces, stem pieces, root segments and seeds of Kaluheenati and Suwandel were selected to isolate endophytic fungi. The plant parts were surface sterilized as follows:

(i) Leaf pieces were cleaned under running tap water (RTW) for $10 \mathrm{~min}$ and surface sterilized by immersing in $70 \%$ ethanol for 1 min followed by $15 \mathrm{~min}$, in $0.25 \% \mathrm{NaOCl}$ and $30 \mathrm{~s}$ in $70 \%$ ethanol; 
(ii) Root segments were cleaned using RTW for $10 \mathrm{~min}$, $75 \%$ ethanol for $40 \mathrm{~s}, 0.5 \% \mathrm{NaOCl}$ for $15 \mathrm{~min}$ and, $70 \%$ ethanol for $30 \mathrm{~s}$;

(iii) Stem pieces were cleaned using RTW for $10 \mathrm{~min}$, $75 \%$ ethanol for $40 \mathrm{~s}, 0.25 \% \mathrm{NaOCl}$ for $10 \mathrm{~min}$, and $70 \%$ ethanol for $40 \mathrm{~s}$;

(iv) Seeds were cleaned using RTW for $10 \mathrm{~min}, 75 \%$ ethanol for $30 \mathrm{~s}, 1.0 \% \mathrm{NaOCl}$ for $5 \mathrm{~min}$ and, $70 \%$ Ethanol for $30 \mathrm{~s}$.

Three consecutive rinses in deionized sterile water were carried out for each of the plant parts and seeds.
Twenty pieces of each of the surface sterilized plant parts and seeds from both varieties were separately transferred to $2 \%(\mathrm{wt} / \mathrm{vol})$ malt extract agar (MEA) medium supplemented with tetracycline $(50 \mathrm{mg} / \mathrm{L})$ under aseptic conditions and incubated for 10 days at room temperature. The endophytic fungal colonies growing from the plant parts and seeds were sub-cultured separately into fresh potato dextrose agar (PDA) medium supplemented with tetracycline $(50 \mathrm{mg} / \mathrm{L})$ and incubated at room temperature. The endophytic fungi were identified to the genus level based on their macroscopic and microscopic features using identification keys.

The percentage rates of colonization and isolation and the dominant fungi percentage were calculated as follows (Goveas et al., 2011):

Percentage colonization rate $=\frac{\text { Total number yielding } \geq 1 \text { isolate }}{\text { Total number of samples in the trial }} \times 100$
Percentage isolation rate $\quad=\quad \frac{\text { Total number of isolates } \times 100}{\text { Total number of samples }}$
Percentage dominance of fungi $=\quad \frac{\begin{array}{c}\text { Number of plant parts yielding each species } \\ \text { during isolation }\end{array}}{\text { Total number of leaf } / \text { stem } / \text { root/seed samples }} \times 100$

Table 1: Endophytic fungal treatments for seedling roots

\begin{tabular}{|c|c|c|}
\hline \multirow[t]{2}{*}{ Treatment } & \multicolumn{2}{|c|}{ Rice variety } \\
\hline & Suwandel & Kaluheenati \\
\hline & $\begin{array}{l}\text { Long storage seedling roots } \\
\qquad \text { (30 replicates) }\end{array}$ & $\begin{array}{l}\text { Long storage seedling roots } \\
\qquad \text { (30 replicates) }\end{array}$ \\
\hline Absidia $(\mathrm{E}+)$ & $\begin{array}{l}\text { Recently harvested seedling roots } \\
\text { (30 replicates) }\end{array}$ & $\begin{array}{l}\text { Recently harvested seedling roots } \\
\text { (30 replicates) }\end{array}$ \\
\hline \multirow[b]{2}{*}{ Cylindrocladium $(\mathrm{E}+)$} & $\begin{array}{l}\text { Long storage seedling roots } \\
\qquad(30 \text { replicates })\end{array}$ & $\begin{array}{l}\text { Long storage seedling roots } \\
\text { (30 replicates) }\end{array}$ \\
\hline & $\begin{array}{l}\text { Recently harvested seedling roots } \\
\qquad \text { (30 replicates) }\end{array}$ & $\begin{array}{l}\text { Recently harvested seedling roots } \\
\text { (30 replicates) }\end{array}$ \\
\hline \multirow[b]{2}{*}{ Control (E-) } & $\begin{array}{l}\text { Long storage seedling roots } \\
\qquad(30 \text { replicates })\end{array}$ & $\begin{array}{l}\text { Long storage seedling roots } \\
\text { (30 replicates) }\end{array}$ \\
\hline & $\begin{array}{l}\text { Recently harvested seedling roots } \\
\qquad(30 \text { replicates })\end{array}$ & $\begin{array}{l}\text { Recently harvested seedling roots } \\
\qquad \text { (30 replicates) }\end{array}$ \\
\hline
\end{tabular}




\section{Effect of fungal endophytes on plant growth}

The effect of the most frequently isolated fungal endophytes i.e. Absidia and Cylindrocladium, on the growth of the two rice varieties Kaluheenati and Suwandel was tested. LSSs (seeds stored at $1{ }^{\circ} \mathrm{C}$ for 20 years) and recently harvested seeds (HSs) of Kaluheenati and Suwandel were cleaned under running tap water for $10 \mathrm{~min}$ and surface sterilized by immersing in $75 \%$ ethanol for $40 \mathrm{~s}$, followed by $10 \mathrm{~min}$ in $0.25 \% \mathrm{NaOCl}$ and $30 \mathrm{~s}$ in $70 \%$ ethanol. This was followed by three consecutive rinses in deionized sterile water. The surface sterilized seeds were then soaked overnight in sterile distilled water. The seeds were germinated by wrapping them with a wet cloth and incubating under room temperature for five days. Absidia and Cylindrocladium were inoculated to these seedling roots by placing $6 \mathrm{~d}$ old seedlings of each LSSs and HSs of Kaluheenati and Suwandel separately for $48 \mathrm{hrs}$ on Absidia and Cylindrocladium cultures grown on PDA, making sure that the roots are in contact with the fungal colony $(\mathrm{E}+)$. The controls (E-) consisted of $6 \mathrm{~d}$ old seedlings of LSSs and HSs of Kaluheenati and Suwandel placed on PDA medium for $48 \mathrm{hrs}$. The details of the treatment combination pattern used for the inoculations are shown in Table 1.

The success of inoculation was confirmed by staining the roots using the trypan blue staining method (Yuan et al., 2010) and observing under the microscope.

The treated $(\mathrm{E}+)$ and untreated $(\mathrm{E}-)$ seedlings were planted in polythene bags (11 inches of diameter and 16 inches of height) filled with soil, which had been autoclaved for $20 \mathrm{~min}\left(121^{\circ} \mathrm{C}\right.$ and $\left.15 \mathrm{lb} / \mathrm{in}^{2}\right)$. Seventy two bags were prepared at a rate of five seedlings per bag, arranged randomly and maintained under 18:6 (day: night) hour period with average temperatures of $30{ }^{\circ} \mathrm{C}$ (day) and $20{ }^{\circ} \mathrm{C}$ (night) in the greenhouse for 3 months. They were watered regularly and Maxicrop $(30 \mathrm{~mL}$ Maxicrop diluted in $10 \mathrm{~L}$ of water) was added to the bags and sprayed on all rice plants as a liquid organic fertilizer.

Ten plants from each treatment were randomly selected at one month intervals from the bags for the measurement of height, fresh weight and dry weight separately. The length of the starting point of stem to the end point of the flag leaf of rice plant was measured as the plant height. Dry weight was measured by oven drying the plants at $60{ }^{\circ} \mathrm{C}$ until a constant weight is reached. The initial fresh weights of seedlings used for each treatment were measured in seven days subjected to germination.

The results were analysed using two-way and balanced ANOVA and Tukey's pairwise comparisons.
Determination of the effect of endophytic fungi on the rice blast pathogen

The effect of endophytic fungal isolates common to both rice varieties on the rice blast pathogen Magnaporthe grisea, was tested in vitro and in planta.

\section{In vitro tests for the effect of endophytes on the rice blast pathogen}

Dual culture assays: $M$. grisea and 22 endophytic fungal isolates common to both rice varieties i.e. Absidia, Cylindrocladium, Phoma, Gliocladium, Cladosporium, Penicillium, Paecilomyces, Acremonium, Rhizoctonia, Rhizophus, Aspergillus sp.1, Aspergillus sp. 2, Aspergillus sp. 3, sterile mycelium (SM) 1, SM 3, SM 4, SM 5, SM 8, SM 9, SM 12, SM 14 and unidentified genus 2, were inoculated onto the two edges of a PDA plate separately and incubated at room temperature for 6 days. Each PDA plate was inoculated with one endophytic fungus and pathogen at the two ends separately in 3 replicates for each endophytic fungus. The colony diameter of $M$. grisea was measured for pathogen inoculated with fungus and alone. The antagonistic activity of each endophytic fungal sp. was expressed as percentage inhibition of the growth of M. grisea.

$\%$ Inhibition $=1-\left\{\frac{\text { Diameter of pathogen colony in tested }}{\text { Diameter of pathogen colony in control }}\right\} \times 100$

The interface of the two colonies, $M$. grisea and fungal endophyte dual was also observed using sticky tape method using the light microscope.

Tests on the effect of crude liquid cultures of endophytic fungi on pathogen growth: $1.5 \mathrm{~mL}$ of potato dextrose broth in $2 \mathrm{~mL}$ appendorf tubes were inoculated separately with the mycelia of 12 endophytic fungal isolates common to both rice varieties i.e. Rhizoctonia, Absidia, Acremonium, Cylindrocladium, Gliocladium, Paecilomyces, Phoma, Penicillium, Aspergillus sp.1, SM 1, SM 4 and SM 8, and incubated by shaking at $140 \mathrm{rev} / \mathrm{min}$ at $25{ }^{\circ} \mathrm{C}$ for $1 \mathrm{wk}$. All broth cultures were freeze-dried and $1.5 \mathrm{~mL}$ methanol was added to each appendorf tubes to extract the metabolites produced by the endophytes.

A $3 \mathrm{~mm}$ (diameter) disc of $M$. grisea grown on PDA was inoculated to the center of a PDA plate. Four $3 \mathrm{~mm}$ discs of sterilized filter papers were dipped in the freeze dried broth culture of each fungal endophyte, dissolved in $1.5 \mathrm{~mL}$ methanol and placed around the agar disc containing $M$. grisea on the plate. Controls consisted of four $3 \mathrm{~mm}$ discs of sterilized filter papers dipped in 
methanol and then placed around the agar disc containing the pathogen on the plate. The plates were incubated under room temperature for $12 \mathrm{~d}$ and the growth of the pathogen was observed. The effect of each broth culture was expressed as the percentage inhibition of growth of the $M$. grisea colony. The results were analysed using ANOVA and Tukey's pair wise comparisons between treatments.

\section{In planta tests for the effect of endophytes on the incidence of rice blast disease}

Three endophytic fungal isolates i.e. Acremonium, Absidia and Penicillium, that showed antagonistic activity against the rice blast pathogen under in vitro conditions were selected for the greenhouse experiment. LSSs of Suwandel were surface sterilized and germinated as mentioned earlier. The resultant seedling roots were inoculated with fungal endophyte isolates by placing them on plates containing Acremonium, Absidia and Penicillium cultures separately for $48 \mathrm{hrs}(\mathrm{E}+)$. Another set of seedling roots were placed on PDA alone as controls (E-). Separately treated and control seedlings were planted in 192 in $^{2}$ polythene bags ( 5 seedlings per bag) filled with autoclaved soil.

Sterile distilled water (SDW) $(10 \mathrm{~mL})$ was added to a 7 day old culture of $M$. grisea and shaken well till the water turns cloudy. The suspension was filtered through a muslin cloth and the spore concentration was determined using $0.5 \mathrm{~mL}$ of the suspension on a counting chamber. Two concentrations of the spore suspension i.e. $1 \times 10^{5}$ and $1 \times 10^{7}$ spores $/ \mathrm{mL}$, were prepared. Few drops of tween 80 were added as an adjuvant.

Leaves of the 45 day old endophyte treated and control plants were surface sterilized using $70 \%$ ethanol. They were slightly damaged with a sterile needle and sprayed

Table 2: Suwandel plants treated with endophyte inoculation and pathogen spore suspension

\begin{tabular}{|c|c|c|c|}
\hline $\begin{array}{l}\text { Established } \\
\text { fungal endophyte }\end{array}$ & \multicolumn{2}{|c|}{$\begin{array}{c}\text { Concentration of spore suspension of } \\
\text { Magneporthe grisea }\end{array}$} & Control \\
\hline Acremonium sp. & $\begin{array}{c}1 \times 10^{5} \text { spores } / \mathrm{mL} \\
(20 \text { replicates })\end{array}$ & $\begin{array}{c}1 \times 10^{7} \text { spores } / \mathrm{mL} \\
(20 \text { replicates })\end{array}$ & $\begin{array}{c}\text { SDW } \\
\text { (10 replicates) }\end{array}$ \\
\hline Absidia sp. & $\begin{array}{c}1 \times 10^{5} \text { spores } / \mathrm{mL} \\
(20 \text { replicates })\end{array}$ & $\begin{array}{c}1 \times 10^{7} \text { spores } / \mathrm{mL} \\
(20 \text { replicates })\end{array}$ & $\begin{array}{c}\text { SDW } \\
\text { (10 replicates) }\end{array}$ \\
\hline Penicillium sp. & $\begin{array}{c}1 \times 10^{5} \text { spores } / \mathrm{mL} \\
(20 \text { replicates })\end{array}$ & $\begin{array}{l}1 \times 10^{7} \text { spores } / \mathrm{mL} \\
(20 \text { replicates })\end{array}$ & $\begin{array}{c}\text { SDW } \\
\text { (10 replicates) }\end{array}$ \\
\hline $\begin{array}{l}\text { Non-inoculated with endophyte } \\
\text { (Control) }\end{array}$ & $\begin{array}{c}1 \times 10^{5} \text { spores } / \mathrm{mL} \\
(20 \text { replicates })\end{array}$ & $\begin{array}{c}1 \times 10^{7} \text { spores } / \mathrm{mL} \\
(20 \text { replicates })\end{array}$ & $\begin{array}{c}\text { SDW } \\
\text { (10 replicates) }\end{array}$ \\
\hline
\end{tabular}

with $M$. grisea spore suspensions in the combinations shown in Table 2.

Each plant was covered separately with clean, transparent polythene bags and wet cotton wool was incorporated to provide moisture. Disease development on the rice leaves was observed daily and the disease incidence was calculated using the following formula.

$\begin{aligned} & \text { Disease } \\ & \text { incidence }(\mathrm{I})\end{aligned}=\left\{\begin{array}{l}\frac{\text { Number of diseased plants }}{\text { Total number of plants }} \\ \text { (healthy and infected) }\end{array}\right\} \times 100$

\section{Detrmination of enzymatic activity of endophytic fungi}

Seven day old pure cultures of the 21 endophytic fungi common to both varieties i.e. Cylindrocladium, Absidia, Acremonium, Penicillium, Cladosporium, Phoma, Gliocladium, Arthroderma, Paecilomyces, Rhizophus, Rhizoctonia, Aspergillus sp.1, Aspergillus sp. 2, Aspergillus sp. 3, SM 1, SM 3, SM 4, SM 5, SM 8, SM 9 and SM 12 were tested for their ability to produce amylase, cellulase, lipase, protease, chitinase, laccase and tyrosinase using protocols described by Maria et al. (2005). The clear zone around each fungal colony was measured. 


\section{RESULTS}

\section{Isolation and identification of endophytic fungi from different plant parts and seeds of Kaluheenati and Suwandel rice varieties}

A total of 41 fungal isolates were associated with 160 samples of leaves, stems, roots and seeds of the rice varieties Suwandel and Kaluheenati. Most fungal genera isolated belonged to the class ascomycetes. Only one genus of basidiomycetes and two zygomycetes were

Table 3: Percentage dominance of endophytic fungal genera in Suwandel

\begin{tabular}{|c|c|}
\hline Endophytic fungi & $\%$ Dominance \\
\hline Absidia & 28.7 \\
\hline Cylindrocladium & 26.2 \\
\hline Aspergillus sp.1 & 16.2 \\
\hline Penicillium & 13.8 \\
\hline Paecilomyces & 13.7 \\
\hline Aspergillus sp. 2 & 12.5 \\
\hline Aureobasidium & 8.7 \\
\hline Rhizoctonia & 8.7 \\
\hline Mortierella & 8.7 \\
\hline Fusarium & 8.7 \\
\hline Gliocladium & 7.5 \\
\hline Phoma & 7.5 \\
\hline Acremonium & 6.3 \\
\hline Arthroderma & 6.3 \\
\hline Varicosporium & 5.0 \\
\hline Cladosporium & 3.7 \\
\hline Rhiophus & 3.7 \\
\hline Aspergillus sp. 3 & 3.7 \\
\hline Emericella & 2.5 \\
\hline Colletotrichum & 1.2 \\
\hline Unidentified genus 1 & 13.8 \\
\hline Unidentified genus 2 & 11.2 \\
\hline Unidentified genis 3 & 11.2 \\
\hline SM 7 & 21.3 \\
\hline SM 1 & 17.5 \\
\hline SM 13 & 13.8 \\
\hline SM 15 & 12.5 \\
\hline SM 8 & 12.5 \\
\hline SM 9 & 12.5 \\
\hline SM 3 & 12.5 \\
\hline SM 12 & 11.2 \\
\hline SM 2 & 8.7 \\
\hline SM 4 & 6.2 \\
\hline SM 6 & 6.2 \\
\hline SM 14 & 6.2 \\
\hline
\end{tabular}

Table 4: Percentage dominance of endophytic fungal genera in Kaluheenati

\begin{tabular}{lc}
\hline Endophytic fungi & \% Dominance \\
\hline Cylindrocladium & 18.7 \\
Absidia & 13.8 \\
Aspergillus sp.1 & 12.5 \\
Cladosporium & 11.2 \\
Penicillium & 8.7 \\
Paecilomyces & 8.7 \\
Phoma & 7.5 \\
Gliocladium & 7.5 \\
Acremonium & 6.2 \\
Aspergillus sp. 2 & 6.2 \\
Rhizoctonia & 6.2 \\
Aspergillus sp. 3 & 5.0 \\
Varicosporium & 3.7 \\
Rhizophus & 3.7 \\
Arthroderma & 2.5 \\
Aureobasidium & 2.5 \\
Unidentified genus 2 & 6.2 \\
Unidentified genus 1 & 3.7 \\
Unidentified genus 3 & 3.7 \\
SM 1 & 16.2 \\
SM 8 & 13.8 \\
SM 17 & 13.8 \\
SM 4 & 12.5 \\
SM 10 & 11.2 \\
SM 11 & 11.2 \\
SM 7 & 8.7 \\
SM 16 & 7.5 \\
SM 3 & 6.2 \\
SM 5 & 3.7 \\
SM 9 & 3.7 \\
SM 13 & \\
\hline & \\
\hline & \\
&
\end{tabular}

identified among the genera associated with both rice varieties. A total 35 different genera of endophytic fungi were isolated from 80 samples of leaves, stems, roots and seeds of Suwandel (Table 3). Similarly, a total 31 different genera of endophytic fungi were isolated from 80 samples of leaves, stems, roots and seeds of Kaluheenati (Table 4).

Absidia was the dominant fungus present in Suwandel (Table 3), while Cylindrocladium was the dominant fungus present in Kaluheenati (Table 4).

\section{Effect of fungal endophytes on rice plant growth}

A significant $(\mathrm{p} \leq 0.05)$ increase in plant height, fresh weight and dry weight were observed in plants grown 
from Absidia and Cylindrocladium inoculated LSSs and freshly HSs of both varieties when compared with the plants grown from the respective non-inoculated seedlings after 1, 2 and 3 months (Table 5, 6 and 7). However, there was no significant difference in these parameters between the two endophytic inocula.

Table 5: Plant heights of the endophyte inoculated and non-inoculated Suwandel and Kaluheenati at first, second and third month after planting

\begin{tabular}{|c|c|c|c|c|}
\hline \multirow[b]{2}{*}{ Month } & \multirow[b]{2}{*}{ Plant type } & \multicolumn{3}{|c|}{ Mean plant height $(\mathrm{cm})$} \\
\hline & & $\begin{array}{c}\text { Absidia } \\
\text { inoculation }\end{array}$ & $\begin{array}{l}\text { Cylindrocladium } \\
\text { inoculation }\end{array}$ & $\begin{array}{c}\text { Control } \\
\text { (non-inoculated) }\end{array}$ \\
\hline \multirow[t]{4}{*}{$1^{\text {st }}$ month } & Suwandel LS & $78.3 \pm 2.92^{\mathrm{a}}$ & $75.0 \pm 5.04^{\mathrm{a}}$ & $51.5 \pm 3.81^{b}$ \\
\hline & Suwandel HS & $62.7 \pm 3.54^{\mathrm{a}}$ & $65.8 \pm 4.46^{\mathrm{a}}$ & $38.8 \pm 2.27^{\mathrm{b}}$ \\
\hline & Kaluheenati LS & $76.6 \pm 4.32^{\mathrm{a}}$ & $68.2 \pm 1.36^{b}$ & $41.1 \pm 1.69^{\mathrm{c}}$ \\
\hline & Kaluheenati HS & $52.8 \pm 2.51^{\mathrm{a}}$ & $60.6 \pm 3.23^{b}$ & $33.8 \pm 4.61^{\mathrm{c}}$ \\
\hline \multirow[t]{4}{*}{$2^{\text {nd }}$ month } & Suwandel LS & $86.2 \pm 4.22^{\mathrm{a}}$ & $84.2 \pm 5.96^{\mathrm{a}}$ & $58.8 \pm 3.16^{\mathrm{b}}$ \\
\hline & Suwandel HS & $79.8 \pm 3.96^{\mathrm{a}}$ & $81.2 \pm 3.82^{\mathrm{a}}$ & $52.7 \pm 2.88^{b}$ \\
\hline & Kaluheenati LS & $82.7 \pm 4.83^{a}$ & $83.3 \pm 1.99^{b}$ & $52.0 \pm 1.64^{\mathrm{c}}$ \\
\hline & Kaluheenati HS & $66.6 \pm 3.63^{\mathrm{a}}$ & $71.0 \pm 7.33^{b}$ & $52.2 \pm 2.20^{\mathrm{c}}$ \\
\hline \multirow[t]{4}{*}{$3^{\text {rd }}$ month } & Suwandel LS & $122.5 \pm 1.42^{a}$ & $108.6 \pm 7.09^{b}$ & $80.1 \pm 5.47^{\mathrm{c}}$ \\
\hline & Suwandel HS & $114.8 \pm 7.53^{\mathrm{a}}$ & $101.9 \pm 4.54^{b}$ & $71.6 \pm 2.86^{\mathrm{c}}$ \\
\hline & Kaluheenati LS & $108.3 \pm 4.21^{\mathrm{a}}$ & $110.9 \pm 5.14^{\mathrm{a}}$ & $69.5 \pm 3.58^{b}$ \\
\hline & Kaluheenati HS & $119.1 \pm 4.46^{\mathrm{a}}$ & $109 \pm 6.35^{b}$ & $71.7 \pm 2.86^{\mathrm{c}}$ \\
\hline
\end{tabular}

LS - Plants germinated from LSSs; HS - plants germinated from HSs; $n=10$; Each value represents mean of ten plants $\pm \mathrm{SD}$; Mean values sharing common letters in each row are not significantly different $(\mathrm{p} \leq 0.05)$

Table 6: Plant fresh weights of the endophytic inoculated and non-inoculated Suwandel and Kaluheenati at first, second and third month after planting

\begin{tabular}{|c|c|c|c|c|}
\hline \multirow[b]{2}{*}{ Month } & \multirow[b]{2}{*}{ Plant type } & \multicolumn{3}{|c|}{ Mean plant height $(\mathrm{cm})$} \\
\hline & & $\begin{array}{c}\text { Absidia } \\
\text { inoculation }\end{array}$ & $\begin{array}{l}\text { Cylindrocladium } \\
\text { inoculation }\end{array}$ & $\begin{array}{c}\text { Control } \\
\text { (non-inoculated) }\end{array}$ \\
\hline \multirow[t]{4}{*}{$1^{\text {st }}$ month } & Suwandel LS & $0.50 \pm 0.07^{\mathrm{a}}$ & $0.51 \pm 0.07^{\mathrm{a}}$ & $0.36 \pm 0.04^{b}$ \\
\hline & Suwandel HS & $0.41 \pm 0.02^{\mathrm{a}}$ & $0.37 \pm 0.05^{\mathrm{a}}$ & $0.26 \pm 0.05^{\mathrm{b}}$ \\
\hline & Kaluheenati LS & $0.45 \pm 0.05^{\mathrm{a}}$ & $0.42 \pm 0.06^{\mathrm{a}}$ & $0.27 \pm 0.04^{b}$ \\
\hline & Kaluheenati HS & $0.39 \pm 0.08^{\mathrm{a}}$ & $0.41 \pm 0.06^{\mathrm{a}}$ & $0.20 \pm 0.04^{b}$ \\
\hline \multirow[t]{4}{*}{$2^{\text {nd }}$ month } & Suwandel LS & $3.41 \pm 0.60^{\mathrm{a}}$ & $3.73 \pm 0.49^{\mathrm{a}}$ & $1.37 \pm 0.26^{b}$ \\
\hline & Suwandel HS & $3.56 \pm 0.46^{\mathrm{a}}$ & $3.01 \pm 0.22^{b}$ & $0.88 \pm 0.15^{c}$ \\
\hline & Kaluheenati LS & $2.94 \pm 0.39^{\mathrm{a}}$ & $2.95 \pm 0.20^{\mathrm{a}}$ & $1.85 \pm 0.33^{b}$ \\
\hline & Kaluheenati HS & $3.15 \pm 0.37^{\mathrm{a}}$ & $2.64 \pm 0.51^{b}$ & $1.07 \pm 0.20^{\mathrm{c}}$ \\
\hline \multirow[t]{4}{*}{$3^{\text {rd }}$ month } & Suwandel LS & $5.14 \pm 0.38^{a}$ & $5.25 \pm 0.45^{\mathrm{a}}$ & $3.04 \pm 0.19^{b}$ \\
\hline & Suwandel HS & $4.96 \pm 0.55^{\mathrm{a}}$ & $4.64 \pm 0.40^{\mathrm{a}}$ & $2.06 \pm 0.14^{b}$ \\
\hline & Kaluheenati LS & $4.78 \pm 0.39^{a}$ & $4.91 \pm 0.52^{\mathrm{a}}$ & $2.88 \pm 0.33^{b}$ \\
\hline & Kaluheenati HS & $5.22 \pm 0.48^{\mathrm{a}}$ & $4.66 \pm 0.43^{b}$ & $1.98 \pm 0.21^{\mathrm{c}}$ \\
\hline
\end{tabular}

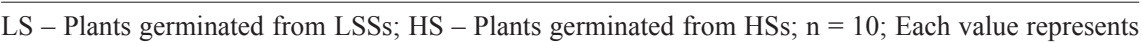
mean of ten plants $\pm \mathrm{SD}$; Mean values sharing common letters in each row are not significantly different $(\mathrm{p} \leq 0.05)$ 
Table 7: Plant dry weights of endophytic inoculated and non-inoculated Suwandel and Kaluheenati at first, secod and third month after planting

\begin{tabular}{|c|c|c|c|c|}
\hline \multirow[b]{2}{*}{ Month } & \multirow[b]{2}{*}{ Plant type } & \multicolumn{3}{|c|}{ Mean plant height $(\mathrm{cm})$} \\
\hline & & $\begin{array}{c}\text { Absidia } \\
\text { inoculation }\end{array}$ & $\begin{array}{l}\text { Cylindrocladium } \\
\text { inoculation }\end{array}$ & $\begin{array}{c}\text { Control } \\
\text { (non-inoculated) }\end{array}$ \\
\hline \multirow[t]{4}{*}{$1^{\text {st }}$ month } & Suwandel LS & $0.133 \pm 0.03^{\mathrm{a}}$ & $0.114 \pm 0.02^{\mathrm{a}}$ & $0.085 \pm 0.01^{\mathrm{b}}$ \\
\hline & Suwandel HS & $0.097 \pm 0.009^{\mathrm{a}}$ & $0.077 \pm 0.012^{\mathrm{a}}$ & $0.057 \pm 0.011^{b}$ \\
\hline & Kaluheenati LS & $0.093 \pm 0.036^{\mathrm{a}}$ & $0.097 \pm 0.015^{\mathrm{a}}$ & $0.070 \pm 0.015^{b}$ \\
\hline & Kaluheenati HS & $0.102 \pm 0.015^{\mathrm{a}}$ & $0.117 \pm 0.011^{\mathrm{a}}$ & $0.065 \pm 0.014^{b}$ \\
\hline \multirow[t]{4}{*}{$2^{\text {nd }}$ month } & Suwandel LS & $0.693 \pm 0.121^{\mathrm{a}}$ & $0.893 \pm 0.141^{b}$ & $0.351 \pm 0.101^{\mathrm{c}}$ \\
\hline & Suwandel HS & $0.778 \pm 0.144^{\mathrm{a}}$ & $0.757 \pm 0.092^{\mathrm{b}}$ & $0.358 \pm 0.062^{c}$ \\
\hline & Kaluheenati LS & $0.803 \pm 0.092^{\mathrm{a}}$ & $0.561 \pm 0.083^{\mathrm{a}}$ & $0.239 \pm 0.047^{\mathrm{b}}$ \\
\hline & Kaluheenati HS & $0.822 \pm 0.092^{\mathrm{a}}$ & $0.653 \pm 0.158^{b}$ & $0.337 \pm 0.054^{\mathrm{c}}$ \\
\hline \multirow[t]{4}{*}{$3^{\text {rd }}$ month } & Suwandel LS & $1.041 \pm 0.091^{\mathrm{a}}$ & $1.138 \pm 0.236^{\mathrm{a}}$ & $0.693 \pm 0.070^{b}$ \\
\hline & Suwandel HS & $1.167 \pm 0.121^{\mathrm{a}}$ & $1.137 \pm 0.166^{\mathrm{a}}$ & $0.721 \pm 0.111^{b}$ \\
\hline & Kaluheenati LS & $1.227 \pm 0.125^{\mathrm{a}}$ & $1.229 \pm 0.146^{\mathrm{a}}$ & $0.571 \pm 0.068^{b}$ \\
\hline & Kaluheenati HS & $1.244 \pm 0.094^{\mathrm{a}}$ & $1.195 \pm 0.152^{\mathrm{a}}$ & $0.637 \pm 0.100^{b}$ \\
\hline
\end{tabular}

LS - Plants germinated from LSSs; HS - Plants germinated from HSs; $n=10$; Each value represents mean of ten plants $\pm \mathrm{SD}$; Mean values sharing common letters in each row are not significantly different $(\mathrm{p} \leq 0.05)$

Microscopic observations of endophytic fungi in inoculated Suwandel and Kaluheenati rice roots

Intra-cellular and inter-cellular fungal hyphae were observed in the root cortex of both varieties growing from LSSs (Figure 1A, 1B, 1C). Similarly, intra and intercellular hyphal growth was seen in the root cortex, and intra-cellular microsclerotia were observed in seedling roots of both varieties grown from HSs.

\section{In vitro tests for the effect of endophytes on the rice blast pathogen}

\section{(a) Dual culture assays}

All 22 endophyte isolates tested inhibited the mycelial growth of $M$. grisea in dual culture assays. Dual cultures of 12 endophytes showed an inhibition zone between the two colonies. $M$. grisea showed $44 \%$ growth in the controls. Some endophytes grew dominantly, while the growth of M. grisea was limited i.e. Penicillium (Figure 2A), Aspergillus sp.1 (Figure 2B) occupied more than $75 \%$ of the plate and the pathogen was spread only to the close vicinity of the point of inoculation. Inhibition percentages of $44.83,46.55,55.16,20.69,32.76$, $16.38,56.9,57.04,37.94$ and 24.44 was shown when M. grisea was cultured with sterile mycelium (SM) 1 (Figure 2C), SM 3, Rhizoctonia, Phoma, Gliocladium,
SM 5, Aspergillus sp. 2, SM 12, Paecilomyces and Cylindrocladium, respectively. Other 10 endophyte colonies; Cladosporium, Absidia (Figure 3A), Acremonium, Rhizophus (Figure 3B), Aspergillus sp. 3, SM 4, SM 8 (Figure 3C), SM 9, SM 14 and unidentified genus 2 grew over the pathogen colony. When the dual culture plates were observed under microscope, all the tested endophytes showed mycoparasitism. In some interactions, thin hyphae of the endophytes coiled around the thicker hyphae of $M$. grisea (Figure 4A). The formation of loops, which would trap the pathogen hyphae (Figure 4B) and the development of clamps by the endophytes on pathogen hyphae were also observed (Figure 4C).

\section{(b) Effect of crude culture filtrates of endophytic fungi}

Crude culture filtrates of the 12 endophytic fungal isolates tested produced significant $(p \leq 0.05)$ reduction in the colony diameter of the pathogen. One way ANOVA showed that there was significant differences ( $p \leq 0.05$ ) between the colony growth of $M$. grisea on control and all the fungal endophyte metabolite added treatments. Tukey's pairwise test showed that there was no significant difference $(\mathrm{p} \leq 0.05)$ between the culture filtrates of Rhizoctonia and Phoma; Acremonium and SM 8; Aspergillus sp.1 and Gliocladium, Paecilomyces 


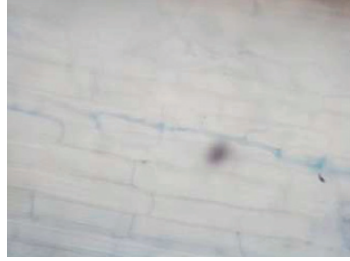

A

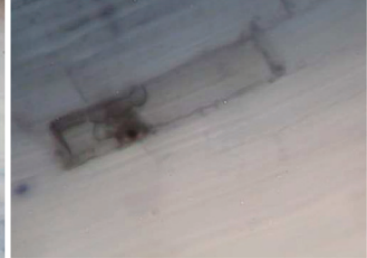

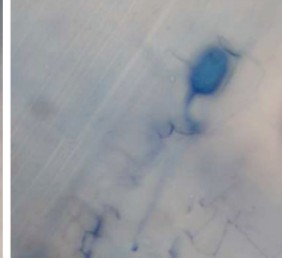

$\mathrm{C}$

Figure 1: Longitudinal sections of roots from Absidia and Cylindrocladium inoculated Suwandel and Kaluheenati plants planted from LSSs (1 month old); A - hyphae growing in root cortex in Cylindrocladium inoculated Kaluheenati $(10 \times 40 \times 4)$; B - hypha in a cortex cell in Absidia inoculated Suwandel $(10 \times 40 \times 5)$; C - hypha within a root cortex cell in Absidia inoculated Suwandel $(10 \times 40 \times 4)$.

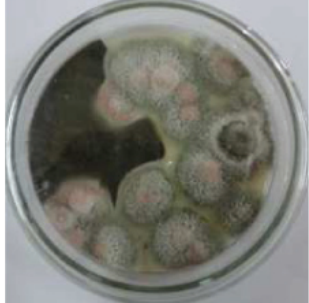

A

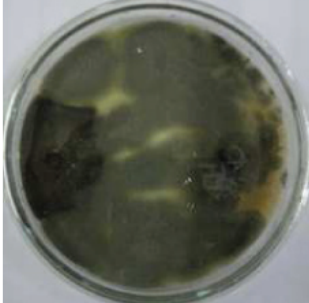

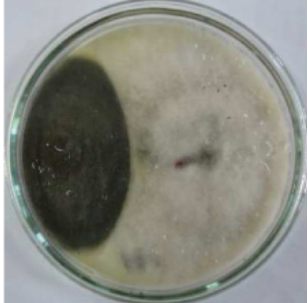

$\mathrm{C}$

Figure 2 : Endophytes and M. grisea in dual culture showing antagonism (6 day old) Colonies on the right hand side represent endophytes; A - Penicillium; B - Aspergillus sp.1; C-SM 1

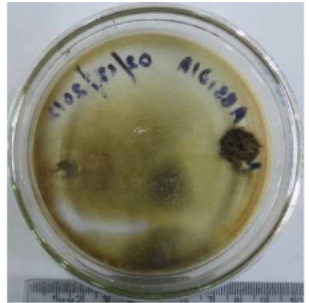

A

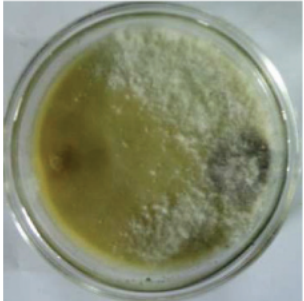

B

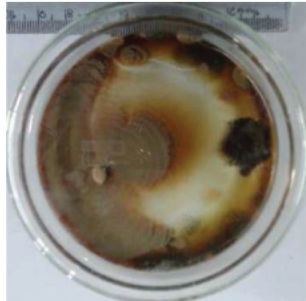

$\mathrm{C}$

Figure 3 : Endophytes and $M$. grisea in dual culture showing competition (6 day old) Colonies on the left hand side represent endophytes: A - Absidia; B - Rhizophus; C - SM 8

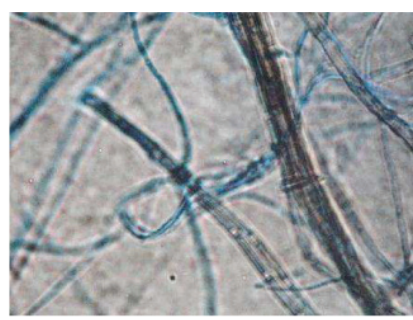

A

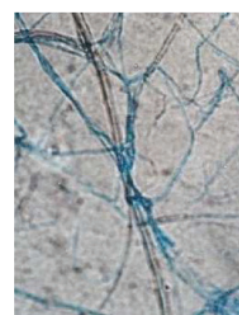

B

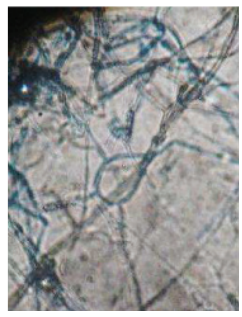

C

Figure 4: Structures formed by endophytes in mycoparasitism of $M$. grisea: A - Endophytes forming clamps on thick pathogen mycelia $(10 \times 40 \times 4)$; B - Thin fungal endophytes hyphae coiling around the thicker hyphae of $M$. grisea $(10 \times 40 \times 4)$; C - Loops formed by endophytes to trap M. grisea $(10 \times 40 \times 3)$. 
and SM 4 in $M$. grisea colony growth inhibition. SM 1 showed the maximum percentage inhibition of the pathogen growth, while both Acremonium and SM 8 showed minimum inhibition of the pathogen growth (Table 8).

Table 8: Percentage inhibition of pathogen growth by fungal endophytes

\begin{tabular}{lc}
\hline Fungal endophyte & \% Inhibition \\
\hline Rhizoctonia & 48.5 \\
Absidia & 34.3 \\
Acremonium & 31.4 \\
Aspergillus sp. 1 & 40 \\
Cylindrocladium & 51.5 \\
Gliocladium & 41.7 \\
Paecilomyces & 40 \\
Phoma & 48.6 \\
Penicillium & 45.7 \\
SM 1 & 54.3 \\
SM 4 & 40 \\
SM 8 & 31.4 \\
Control (methanol) & 0 \\
\hline
\end{tabular}

\section{In planta tests for the effect of endophytes on rice} blast disease incidence

There were no symptoms on Suwandel rice leaves inoculated with the spore suspensions of $1 \times 10^{5}$ spores $/ \mathrm{mL}$ in both treated and control plants. Disease symptoms were observed only on the rice leaves of plants grown from Penicillium inoculated seedlings and the controls treated with $1 \times 10^{7}$ spores $/ \mathrm{mL}$ concentration of the spore suspension (Table 9). The symptoms observed were

Table 9: Disease incidence in Suwandel plants pre-treated with endophytes

\begin{tabular}{|c|c|c|}
\hline $\begin{array}{c}\text { Concentration } \\
\text { (spores/mL) of } \\
\text { pathogen inoculum }\end{array}$ & Pre-treatment & $\begin{array}{c}\text { Disease } \\
\text { incidence \% }\end{array}$ \\
\hline
\end{tabular}

$\begin{array}{ccc}1 \times 10^{5} & \text { Acremonium inoculation } & 0 \\ & \text { Absidia inoculation } & 0 \\ & \text { Penicillium inoculation } & 0 \\ & \text { Non inoculation }(\mathrm{E}-) / \text { control } & 0 \\ & \text { Acremonium inoculation } & 0 \\ \text { Absidia inoculation } & 0 \\ \text { Penicillium inoculation } & 20 \\ & \text { Non inoculation }(\mathrm{E}-) / \text { control } & 45\end{array}$

elliptical gray-white lesions with reddish edges. A yellow zone around the lesion after nineteen days and yellowing of leaves after twenty five days of pathogen inoculation was observed.

A disease incidence of $45 \%$ was observed in (E-) plants sprayed with the spore suspension at $1 \times 10^{7}$ spores/mL (control). Elliptical gray-white lesions with reddish edges developed on the leaf blade 10 days after pathogen inoculation. An average of four lesions were initially observed on leaf blades of endophyte non-inoculated plants. After four days of incubation it increased to seven, and lesions were seen on the leaf sheaths as well as on the leaf blades. The lesion number increased to 12 after five days of incubation. A yellow zone was observed surrounding some lesions, whilst the leaves became yellow in colour. Further development of lesions was not observed with time.

Twenty percent of disease incidence was observed in plants grown from seedlings pre inoculated with a Penicillium sprayed with spore suspension of $1 \times 10^{7}$ spores $/ \mathrm{mL}$. Lesions developed only on the leaf blade 15 days after pathogen inoculation. Three lesions were initially observed on leaf blades. After a week of incubation it increased up to five, but further development of the lesions were not observed. After the end of the first week lesion development of the leaves became yellow in colour.

Rice blast symptoms was not observed $(0 \%$ of disease incidence) in plants pre-inoculated with Acremonium and Absidia and treated with $1 \times 10^{7}$ spores $/ \mathrm{mL}$ concentration of the spore suspension; plants pre-inoculated with Acremonium, Absidia and Penicillium and control treatments, which were carried out using sterile distilled water in place of the rice blast pathogen treated with $1 \times 10^{5}$ spores $/ \mathrm{mL}$ concentration of the spore suspension.

\section{Determination of enzymatic activity of fungal endophytes}

Lipase was produced by sixteen and cellulase by fifteen of the fungal endophytes tested, while amylase and protease were produced by thirteen of the fungi tested. None showed chitinase, laccase and tyrosinase activity (Table 10). The ability to produce these enzymes was distributed amongst the strains tested. Acremonium, Penicillium, Rhizophus, Aspergillus sp.1 and SM 1 showed activity of all four enzymes (Table 10). The highest amylase, cellulase, lipase and protease activity was shown by Cladosporium, Cylindrocladium, Gliocladium and Absidia, respectively. 
Table 10: Substrate utilisation of endophytic fungi $(n=3$; mean \pm SD)

\begin{tabular}{lcccc}
\hline Endophytes & \multicolumn{4}{c}{ Diameter of clear zone $(\mathrm{cm})$} \\
& Amylase & Cellulase & Lipase & Protease \\
\hline & & & & \\
Cylindrocladium & $6.48 \pm 0.26$ & $7.63 \pm 0.15$ & $2.96 \pm 0.1$ & 0 \\
Absidia & 0 & $1.45 \pm 0.03$ & $4.42 \pm 0.09$ & $7.63 \pm 0.15$ \\
Acremonium & $6.33 \pm 0.25$ & $5.23 \pm 0.07$ & $4.12 \pm 0.23$ & $8.1 \pm-0.22$ \\
Penicillium & $8.2 \pm 0.36$ & $6.38 \pm 0.1$ & $2.31 \pm 0.3$ & $3.5 \pm 0.25$ \\
Cladosporium & $7.06 \pm 0.37$ & $3.33 \pm 0.02$ & 0 & $4.8 \pm 0.04$ \\
Phoma & $3.52 \pm 0.43$ & $3.95 \pm 0.3$ & 0 & $6.38 \pm 0.06$ \\
Gliocladium & $2.91 \pm 0.12$ & 0 & $7.1 \pm 0.23$ & 0 \\
Arthroderma & 0 & 0 & $2.67 \pm 0.09$ & 0 \\
Paecilomyces & 0 & $2.17 \pm 0.18$ & $2.83 \pm 0.07$ & $4.52 \pm 0.30$ \\
Rhizophus & $6.71 \pm 0.22$ & $3.95 \pm 0.23$ & $6.61 \pm 0.33$ & $3.22 \pm 0.35$ \\
Rhizoctonia & 0 & 0 & $3.4 \pm 0.26$ & $3.4 \pm 0.09$ \\
Aspergillus sp. 1 & $2.86 \pm 0.32$ & $4.31 \pm 0.08$ & $5.51 \pm 0.12$ & $2.1 \pm 0.2$ \\
Aspergillus sp. 2 & $3.83 \pm 0.22$ & $3.6 \pm 0.1$ & 0 & 0 \\
Aspergillus sp. 3 & 0 & $1.8 \pm 0.02$ & $3.45 \pm 0.32$ & $4.7 \pm 0.4$ \\
SM 1 & $6.88 \pm 0.24$ & $3.48 \pm 0.21$ & $7.4 \pm 0.56$ & $5.83 \pm 0.31$ \\
SM 3 & $3.3 \pm 0.2$ & $1.36 \pm 0.02$ & $3.02 \pm 0.02$ & 0 \\
SM 4 & 0 & $4.91 \pm 0.31$ & 0 & $2.6 \pm 0.08$ \\
SM 5 & 0 & 0 & $1.89 \pm 0.04$ & $2.36 \pm 0.14$ \\
SM 8 & $3.3 \pm 0.2$ & $1.86 \pm 0.09$ & 0 & 0 \\
SM 9 & 0 & $3.29 \pm 0.1$ & $6.4 \pm 0.25$ & 0 \\
SM 12 & $3.56 \pm 0.11$ & 0 & $2.72 \pm 0.25$ & 0 \\
\hline & & & &
\end{tabular}

\section{DISCUSSION}

In this study, fungal endophytes from two traditional rice varieties i.e. Suwandel and Kaluheenati were isolated and used to examine their ability to enhance rice plant growth and control the incidence of rice blast disease.

Since endophytes are organisms inhabiting numerous plant organs at some time in their life and colonize internal plant tissues asymptomatically, apparently healthy rice plants from both varieties and a range of plant parts were selected to increase the probability of isolating novel endophytes. One of the critical requirements for isolating endophytes is the use of fresh plant material. Therefore, isolations were done from the material collected from paddy fields within 24 hrous.

Roots (Yuan et al., 2009) and stems (Yuan et al., 2010) have been used for the isolation of endophytes in rice plants. In the present study, seeds, roots, leaves and stems of both rice varieties were used and endophytes were isolated from all the parts used.

In the isolation of endophytes, surface sterilization is a critical step as it is essential to eliminate epiphyte microbes present on the plant surface. Therefore, the above mentioned plant organs were subjected to different surface sterilizing regimes in order to select the most appropriate method. After surface sterilization, plant parts from the two rice varieties were plated separately on MEA medium supplemented with tetracycline $(50 \mathrm{mg} / \mathrm{L})$. Tetracycline was added as an antibiotic to restrain bacterial growth until the emergence of fungal colonies from the plant segments.

Yuan et al. (2010) have isolated 58 endophytes from 204 root segments from 15 wild rice plants. The members of the genera Phialocephala, Pericornia, Trichoderma, Fusarium, Penicillium, Cylindrocarpon, Paecilomyces, Cylindrocladium and Phialophora were most frequently isolated from the roots. Most of them were ascomycetes and a few were basidiomycetes. Some of the isolates were identified as being members of the commonly observed genera of soil fungi, e.g. Fusarium, Penicillium, Trichoderma and Paecilomyces. The data (Yuan et al., 2010) demonstrates that the roots of wild rice are associated with a surprisingly rich endophyte community. Similarly, in the present study, most fungal genera identified were from the class ascomycetes. Only 1 genus of basidiomycetes and 2 genera of 
zygomycetes were identified among the morphologically identified genera isolated from both rice varieties. The identified ascomycetes fungi belonged to 15 different genera.

Some of isolates were identified as being members of commonly observed genera of soil fungi, e.g. Fusarium, Penicillium, Rhizophus, Rhizoctonia, Absidia, Aspergillus and Paecilomyces are representatives of these genera that have been identified as endophytes in both traditional rice roots. Similarly, some isolates from wild rice were identified as being members of commonly observed genera of soil fungi, e.g. Fusarium, Penicillium, Trichoderma and Paecilomyces. These fungi are characteristically free living saprophytes that can also be opportunistic root symbionts. Except Varicosporium and Mortierella, other isolated endophytes are most frequently found endophytes in literature (Yuan et al., 2010).

The impact of fungal endophytes on the growth of rice plants was tested using the most frequently isolated and highest occurring endophytes i.e. Absidia, Cylindrocladium. As endophytes are reported to enter the plants horizontally through seeds (Zabalgogeazcoa, 2008), seeds from both varieties were used to inoculate the above mentioned fungi. According to Li et al. (2004), seeds lose viable endophytes during long-term storage and the resultant plants from long-term storage germinated seeds are endophyte-free. Therefore, seedlings/plants grown from LSSs are considered as endophyte-free and they proved to be so when tested by culturing on artificial media in the present study. Endophytes naturally occur in recently harvested seeds and they were observed through isolation into artificial media. In this study, endophytes were artificially inoculated to LSSs and HSs. Controls were without inoculation of endophytes to both LSSs and freshly harvested seeds. From the results of this experiment, it can be concluded that plant growth can be enhanced by increasing the levels of endophytic mycoflora in plants as well as introducing the mycoflora to plants. However, no noticeably high growth enhancement was observed in the plants grown from both treated and untreated freshly harvested seeds as compared to treated and untreated plants grown from LSSs, indicating that the natural levels were not sufficient to do so. Therefore, it indicates that an inoculum consisting of one or more endophyte(s) is needed to obtain improved growth. Since sterilized soil was used to grow these rice plants, this significant increase is correlated with the direct or indirect impact of the endophytes on rice plant growth. Thus, endophyte inoculation always resulted in higher plant growth than control plants.
According to Mandyam and Jumpponen (2005), in endophyte inoculated roots, dark septate endophytic (DSE) fungi produced arrays of hydrolytic enzymes that can access and utilize sources of C, N and P in soil. Thus, hydrolytic enzymes produced by root-inhabiting endophytic fungi lead to the improvement of plant growth due to increased utilization of organic nutrients by their enzymatic activities. In the present study, some of the endophytes tested showed amylase, lipase, cellulase and protease enzymatic activity. The high lipase and cellulase activities suggest the ability to use fats and cellulose as energy sources and the considerable amylase and protease production observed suggests the ability to use starch and proteins as energy sources. In particular, the production of amylase, cellulose, protease, and lipase by a large number of different endophytes in rice provide a wider spectrum of biological properties that can function at diverse $\mathrm{pH}$ and temperature ranges. A previous research study (Li et $a l$, 2004) showed that several endophytic Neotyphodium species found in perennial rye grass secreted hydrolytic enzymes i.e. chitinase, proteases, glucanase, that are involved in the digestion of the insect cuticle and mycoparasitism. Also they showed that Neoatyphodiuminfected rye grasses have the ability to resist diseases and herbivoury infections (Li et al., 2004).

Currently, the role of biological control agents has become increasingly crucial, and in several cases, complementing or even replacing the chemical counterparts where antagonistic fungi play an important part. Endophytes can act as potential biological control agents through a number of mechanisms and their ability to reduce disease incidence has been reported (Pandya \& Saraf, 2009).

In a previous study, fungal endophytes isolated from healthy Theobroma cacao tissues were screened in vitro for antagonism against major pathogens of cacao. Of the tested endophytic morphospecies, most of them showed in vitro antagonism against the pathogens Moniliophthora roreri (frosty pod rot), M. perniciosa (witches broom) and Phytophthora palmivora (black pod rot) (Mejia et al., 2008).

In the present study, fungal endophytes isolated from healthy plant organs of both rice varieties were tested for their ability to control the growth of the most common and economically important pathogen of rice, $M$. grisea both in vitro and in planta. Dual-culture method assessed the effect on the growth of pathogen mycelium. It was determined by measuring the radial growth of the pathogen colony when it was incubated with the fungal endophytes. The most important parameter determining 
the antagonistic activity was percentage inhibition of the pathogen growth with respect to the pathogen solely grown on PDA. Some endophytes tended to slow the growth of the pathogen when compared to the control, suggesting the production of antibiotic chemicals by tested endophytes. Another mechanism of pathogen growth restriction by fungi is competition. In the present study, pathogen growth was limited to its inoculation point by some endophytic fungi and this could be due to competition. This implies that diffusible antibiotics may be produced when they interact with the pathogens.

Various structures produced by fungal endophytes to parasitize the pathogen were observed under the high power of the light microscope and these might have a role in the control of the growth of the pathogen. Some hyphae of fungal endophytes coiled around the much dense $M$. grisea mycelia. Another type of a structure formed was clamps on the pathogen hyphae. Fungi trapping loops were also observed in mycoparasitic activity of fungal endophytes. All these structures were formed to adhere on to the pathogen while they may develop haustoria into the pathogen hyphae to obtain nutrients.

In a study by Mejia et al. (2008), endophytic Trichoderma hyphae coiling around Moniliophthora roreri hyphae or producing short branches tightly surrounding the $M$. roreri hyphae was observed. Also internal growth of Trichoderma isolates within Phytophthora spp. was observed often together with the disintegration of cell walls (Mejia et al., 2008).

Inhibitory effect of the culture filtrates of some endophytes was assessed by measuring the radial growth of the pathogen colony in the presence of four discs of sterilized filter paper dipped into the freeze dried broth culture of tested fungal endophyte placed around the pathogen. The most important parameter determining the metabolite activity was percentage inhibition of the pathogen growth with respect to the pathogen grown on PDA surrounding sterile filter paper discs dipped in methanol. One way ANOVA revealed that there was significant difference between the control and all the fungal endophyte metabolites to inhibit the pathogen growth. The antagonistic activity statistically significant of metabolite extracts showed that the isolate SM 1 is most successful in controlling the pathogens because it showed a maximum pathogen growth inhibition. Tian et al. (2003) have found that metabolites of Fusarium spp., Paecilomyces spp., Aspergillus spp. and Penicillium spp. to have antagonism against Magnaporthe grisea, Rhizoctonia solani and Xanthomonas oryzae pv. oryzae.
These results demonstrated that some endophytic fungi have the potential for inhibiting the growth of $M$. grisea. Therefore, antagonistic activity of the extracted and purified metabolites from these fungi may also be used safely in agriculture to control the rice blast pathogen.

Greenhouse experiments were conducted to test the effect of endophytes on disease incidence in planta. According to the observations of biological control activity of the fungal endophytes in planta, $1 \times 10^{7}$ spores/ $\mathrm{mL}$ concentration of the spore suspension was effective in developing the disease than the $1 \times 10^{5}$ spores $/ \mathrm{mL}$ spore suspension. Although Penicillium was effective in controlling the mycelia growth of the pathogen in vitro, it was less effective in reducing the symptom development and disease incidence in planta. However, no symptoms appeared in Acremonium and Absidia pre-established plants. Thus the endophytes may be having a potential to prevent pathogen growth in rice plants. It is possible that these isolates are endophytic strains specialized as nonpathogenic mutualistic endophytes on rice, but more experiments are needed to determine what the genetic relationships of these apparently mutualistic associations.

It is clear that in vitro results do not necessarily translate directly to what occurs in planta. Nonetheless, in vitro studies and their results are particularly useful for identifying likely candidates for bio control and for making educated guesses concerning the mechanisms by which they reduce pathogen damage (Mejia et al., 2008). Overall, these results strongly suggest that the diverse assemblage of endophyte species associated with traditional rice play an integral role in the resistance of their host plant to pathogen damage, and that endophytes can potentially be used as effective bio control agents.

In this study, the high lipase and cellulase activities suggest their ability to use fats and cellulose as energy sources. The considerable amylase and protease production observed, suggest their ability to use starch and proteins as energy sources. In particular, the production of amylase, cellulase, protease, and lipase by a large number of different endophytes in rice provide a wider spectrum of biological properties that can function at diverse $\mathrm{pH}$ and temperature ranges. A previous research showed that several endophytic Neotyphodium species found in perennial rye grass secrete hydrolytic enzymes i.e. chitinase, proteases, glucanase which are involved in the digestion of insect cuticle and mycoparasitism. Also they showed that Neoatyphodium-infected rye grasses have the ability to resist diseases and herbivoury infections (Li et al., 2004) 
None of the fungi showed laccase, chitinase and tyrosinase activity. The endophytic nature of these fungi might be the reason for the lack of laccase activity, since an active enzyme might damage the host plant. Tyrosinase is a common enzyme participating in lignin degradation by detoxifying the breakdown products. Colloidal chitin is prepared from the chitin flakes as a substrate to assess the chitinase activity of endophytes (Maria et al., 2005). Therefore different solvents were used for dissolving chitin flakes; $\mathrm{CaCl}_{2} \cdot 2 \mathrm{H}_{2} \mathrm{O}$-saturated methanol, 8 wt \% NaOH4 wt \% urea aqueous solution and hexafluoroacetone (Chang et al., 2011), but any of the solvents were not success. However chitin flakes were dissolved to some extent, according to Shanmugaiah et al. (2008) method, but there was not given any positive results from tested fungal endophytes.

Fungal secreted proteins are of interest in endophytehost interactions because they act at the interface of the two species. In order to maintain a stable symbiosis, endophytes secrete varieties of extracellular enzymes that contribute to colonization and growth. Substrate utilization studies and isozyme analysis have demonstrated that most endophytes are able to utilize most plant cell components. But the presence of endophyte hydrolytic enzymes within the plant also have the function of suppressing plant pathogen activities directly and have the capability of degrading the cell walls of fungi, thus it leads to plant resistance (Wang \& Chuan, 2011).

Once optimized, an inoculum consisting of the more effective fungal endophytes could be developed to enhance the performance of the rice varieties. Traditional rice varieties were selected in this study as they are more amenable to organic farming practices of the suggested type.

\section{CONCLUSION}

- A high fungal diversity and a somewhat similar fungal genera composition occur in both traditional rice varieties tested and most of them belong to the class ascomycetes.

- A diverse assemblage of fungal endophytes associated with traditional rice varieties affect the growth of the rice pathogen $M$. grisea both in vitro and in planta.

- Some fungal endophytes isolated from/present in the two rice varieties can increase rice plant growth and some can reduce the disease incidence of the rice blast disease caused by M. grisea.

- The tested endophytic fungi show a range of mechanisms of antagonistic activity such as antibiosis, competition for substrate and mycoparasitism.
- Fungal endophytes in rice show multiple enzymatic activity.

\section{REFERENCES}

1. Baynes M.A. (2011). Endophytic fungal communities of Bromustectorum: mutualisms, community assemblages and implications fir invasion. MSc thesis, University of Idaho, USA.

2. Chang C., Chen S. \& Zhang L. (2011). Novel hydrogels prepared via direct dissolution of chitin at low temperature: structure and biocompatibility. Journal of Materials Chemistry 21: $3865-3871$.

DOI: http://dx.doi.org/10.1039/c0jm03075a

3. Coombs J.T. (2002). Antibiotics for Wheat. Science Now. The National Science Forum. August 20 - 22,

4. Goveas S.W., Madtha R., Nivas S.H. \& D'Souza L. (2011). Isolation of endophytic fungi from Coscinium fenestratum - a red listed endangered medicinal plant. EurAsian Journal of BioSciences 5: 48 - 53 .

DOI: http://dx.doi.org/10.5053/ejobios.2011.5.0.6

5. Higa T. \& Parr J.F. (1994). Beneficial and Effective Microorganisms for a Sustainable Agriculture and Environment. Japan International Nature farming Research Center Publication. International Nature Farming Research Center, Atami, Japan. Available at: http://www.agriton.nl/ higa.html

6. Latch G.C.M., Christensen M.J. \& Samuels G.J. (1984). Five endophytes of Lolium and Festuca in New Zealand. Mycotaxon 20: 535 - 550 .

7. Li H.M., Sullivan R., Moy M., Kobayashi D.Y. \& Belanger F.C. (2004). Expression of a novel chitinase by the fungal endophyte in Poaampla. Mycologia 96(3): 526 - 536. DOI: http://dx.doi.org/10.2307/3762172

8. Mandyam K. \& Jumpponen A. (2005). Seeking the exclusive function of the root-colonising dark septate endophytic fungi. Journal of Studies in Mycology 53: 173 - 189. DOI: http://dx.doi.org/10.3114/sim.53.1.173

9. Maria G.L., Sridhar K.R. \& Raviraja N.S. (2005). Antimicrobial and enzyme activity of mangrove endophytic fungi of southwest coast of India. Journal of Agricultural Technology 1: $134-143$.

10. Mejia L.C., Rojas E.I., Maynard Z., Bael S.V., Arnold A.E., Hebber P., Samuels G.J. \& Robbins N. (2008). Endophytic fungi as biocontrol agents of Theobroma cacao pathogens. Biological Control 46: 4 - 14.

DOI: http://dx.doi.org/10.1016/j.biocontrol.2008.01.012

11. Montesinos E. (2003). Plant-associated microorganisms: a view from the scope of microbiology. International Microbiology 6(4): $221-223$.

DOI: http://dx.doi.org/10.1007/s10123-003-0141-0

12. Morgan-Jones G. \& Gains W. (1982). Notes on hyphomycetes. XLL an endophyte of Festucaarundinaeea and the anamorph of Epichloe typhina, new taxa in one of two new sections of Acremonium. Mycotaxon 15: 311.

13. Naturland E.V. (2002). Organic farming in the tropics and subtropics. International Microbiology 6: $221-223$. 
14. Pandya U. \& Saraf M. (2009). Application of fungi as a biocontrol agent and their bio fertilizer potential in agriculture. J.Adv.Dev.Res 1(1): 90 - 99.

15. Sawka H. (2004). Endophyte-enhanced grasses. Microbial Ecology 30: 343 - 356.

16. Shanmugaiah V., Mathivanan N., Balasubramanian N. \& Manoharan P.T. (2008). Optimization of cultural conditions for production of chitinase by Bacillus laterosporous MML2270 isolated from rice rhizosphere soil. African Journal of Biotechnology 7: 2562 - 2568. Available at: http://www.ajol.info/index.php/ajb/article/download/ 59092/47397

17. Tian X.L., Cao L.X., Tan H.M., Zeng Q.G., Jia Y.Y., Han W.Q. \& Zhou S.N. (2003). Study on the communities of endophytic actinomycetes from rice and their antipathogenic activities in vitro. World Journal of Microbiology and Biotechnology 20: 303 - 309. Available at : http://www. paper.edu.cn/scholar/downpaper/zhoushi ning-2
18. Wang J.G.H. \& Chuan C. (2011). Fungi in their own right. Fungal Genetics and Biology 27: $134-145$.

19. Yuan Z., Su Z., Mao L., Peng Y., Yang G., Lin F. \& Zhang C. (2010). Distinctive endophytic fungal assemblage in stems of wild rice (Oryza granulata) in china with special reference to two species of Muscodor (Xylariacea). The Journal of Microbiology 49(1): $15-23$.

DOI: http://dx.doi.org/10.1007/s12275-011-0213-3

20. Yuan Z., Zhang C., Lin F. \& Kubicek C.P. (2009). Identity, diversity, and molecular phylogeny of the endophytic mycobiota in the roots of rare wild rice (Oryza granulate) from a nature reserve in Yunnan, China. Applied and Environmental Microbiology 76(5): 1642 - 1652. DOI: http://dx.doi.org/10.1128/AEM.01911-09

21. Zabalgogeazcoa I. (2008). Fungal endophytes and their interaction with plant pathogens. Spanish Journal of Agricultural Research 6: 138 - 146.

DOI: http://dx.doi.org/10.5424/sjar/200806s1-382 